\title{
Comparison of the diagnostic value of serum pancreatic isoamylase and immunoreactive trypsin measurement in patients with cystic fibrosis
}

\author{
RC BROW'N, DM CHALMERS, VL ROWE, J KELLEHER, JM LITTLEWOOD, \\ MS LOSOWSKY
}

From the Departments of Medicine and Paediatrics, St James's University Hospital, Leeds

SUMMARY We have measured serum immunoreactive trypsin (IRT) and serum pancreatic isoamylase (PIA) activities using commercially available kits in 37 cystic fibrosis (CF) patients and 46 hospital controls of similar age range. Immunoreactive trypsin was more often abnormal than PIA (26/37 v 18/37 abnormal respectively); IRT will be particularly useful as an additional diagnostic test in older children, in whom interpretation of the sweat test may be difficult, as $14 / 15$ CF patients aged over 10 years had abnormal IRT results. Less than half of our patients who were aged between one and nine years had abnormal IRT activity, limiting the value of the test, though a low activity would still support the diagnosis of CF. Comparison with faecal fat estimations in 31 patients suggests that neither IRT nor PIA can be used as a non-invasive test of pancreatic function in order to identify those few CF patients who do not require pancreatic enzyme supplements.

The clinical diagnosis of cystic fibrosis (CF) is usually confirmed by an abnormal sweat test. However sweat tests may give misleading results unless carefully performed, ${ }^{1}$ and some $\mathrm{CF}$ patients have normal or equivocal sweat electrolyte concentrations. ${ }^{2}$ Under these circumstances pancreatic function tests are of diagnostic value, as CF patients almost invariably have abnormal results. ${ }^{3}$ Standard tests of pancreatic function require duodenal intubation, which is unpleasant and time-consuming. The finding of a low serum pancreatic isoamylase (PIA) has been suggested both as an additional diagnostic test for $\mathrm{CF}^{4}$ and as a non-invasive test of pancreatic function. ${ }^{5}$ Previously described methods for the separation of pancreatic from salivary isoamylase have been too laborious for routine use, but a simpler method for PIA measurement using a selective inhibitor of salivary amylase to distinguish the pancreatic and salivary components of the total serum amylase is now available. ${ }^{7}$ We have reassessed the value of PIA measurement using this method, and have compared it with serum immunoreactive trypsin measurement (IRT), as this has also been proposed as a diagnotic test for CF. ${ }^{8}$

Accepted for publication 24 September 1981

\section{Patients and methods}

Venous blood samples were taken from 37 patients (aged two months to $19 \mathrm{yr}$ ) with CF and from 46 controls (aged three months to $17 \mathrm{yr}$ ). The diagnosis of $\mathrm{CF}$ was confirmed by a sweat sodium and chloride $>60 \mathrm{mmol} / \mathrm{l}$. The controls were hospital patients with various conditions including asthma, recurrent chest infection, non-specific abdominal pains and malabsorption without evidence of pancreatic insufficiency. No patient or control had either renal or parotid disease. Serum was separated within six hours, and stored at $-20^{\circ} \mathrm{C}$ until assayed within three months of collection.

Total serum amylase, pancreatic isoamylase and salivary isoamylase were measured using a commercially available kit (Phadebas Isoamylase Test, Pharmacia Diagnostics AB, Uppsala). Serum IRT was measured by radioimmunoassay kit (Hoechst UK Ltd).

Faecal fat measurements were made on two day faecal collections from 31 of the CF patients. ${ }^{9}$ All were taking pancreatic enzyme supplements during the collections. Daily fat output was calculated by applying a correction for the content of the non-absorbable faecal marker polyethylene 
Total amylase, salivary amylase, pancreatic isoamylase and \% pancreatic isoamylase activities in controls and CF patients of various ages. Values are median values and $95 \%$ confidence limits after logarithmic transformation

\begin{tabular}{|c|c|c|c|c|c|c|c|c|c|c|}
\hline \multirow[t]{2}{*}{ Age $(y r)$} & \multicolumn{2}{|c|}{ Number } & \multicolumn{2}{|c|}{ Total amylase $(U / l)$} & \multicolumn{2}{|c|}{ Salivary isoamylase $(U / I)$} & \multicolumn{2}{|c|}{ Pancreatic isoamylase $(U / I)$} & \multicolumn{2}{|c|}{$\%$ pancreatic isoamylase } \\
\hline & $C O$ & $C F$ & $\mathrm{CO}$ & $C F$ & $C O$ & $C F$ & $\mathrm{CO}$ & $C F$ & $\mathrm{CO}$ & $C F$ \\
\hline Up to 1 & 4 & 4 & $\begin{array}{l}91 \cdot 5 \\
(16-500)\end{array}$ & $\begin{array}{l}100 \\
(25-271)\end{array}$ & $\begin{array}{l}38 \cdot 5 \\
(7-409)\end{array}$ & $\begin{array}{l}71 \cdot 5 \\
(6-401)\end{array}$ & $\begin{array}{l}25 \\
(6-128)\end{array}$ & $\begin{array}{l}19 \cdot 5 \\
(7-61)\end{array}$ & $\begin{array}{l}51 \cdot 5 \\
(6-100)\end{array}$ & $\begin{array}{l}34 \cdot 5 \\
(3-100)\end{array}$ \\
\hline $1-4 \cdot 9$ & 16 & 9 & $\begin{array}{l}234 \\
(89-539)\end{array}$ & $\begin{array}{l}210 \\
(93-398)\end{array}$ & $\begin{array}{l}187 \\
(48-519)\end{array}$ & $\begin{array}{l}139 \\
(48-348)\end{array}$ & $\begin{array}{l}53 \cdot 5 \\
(16-169)\end{array}$ & $\begin{array}{l}33 \\
(10-348)\end{array}$ & $\begin{array}{l}25 \cdot 5 \\
(8-66)\end{array}$ & $\begin{array}{l}22 \\
(5-100)\end{array}$ \\
\hline $5-19$ & 26 & 24 & $\begin{array}{l}186 \\
(44-567)\end{array}$ & $\begin{array}{l}190 \\
(100-336)\end{array}$ & $\begin{array}{l}117 \\
(28-319)\end{array}$ & $\begin{array}{l}168^{*} \\
(88-294)\end{array}$ & $\begin{array}{l}67 \cdot 5 \\
(27-168)\end{array}$ & $\begin{array}{l}19 \cdot 5 * * \\
(2-124)\end{array}$ & $\begin{array}{l}36 \\
(14-100)\end{array}$ & $\begin{array}{c}9 * * \\
(2-46)\end{array}$ \\
\hline
\end{tabular}

${ }^{*} \mathrm{p}<0.05,{ }^{* *} \mathrm{p}<0.01$, compared to controls of the same age-group.

CO controls. CF - cystic fibrosis patients.

glycol 4000 given in a dose of $500 \mathrm{mg}$ tds for 5 days before collection. ${ }^{10}$

The enzyme results were significantly positively skewed. Results were therefore expressed as median values, with $95 \%$ confidence limits calculated after logarithmic transformation. Statistical comparisons between groups were made by Wilcoxon rank sum tests, and correlations by Spearman's rank test.

\section{Results}

Serum total amylase, salivary amylase and PIA were found to increase after the age of one year in control subjects, and activities are shown for different age-groups (up to $1,1-5$, and $5+\mathrm{yr}$ ) in the Table Total amylase activities in $\mathrm{CF}$ patients were similar to control activities at all ages. Salivary amylase activities were similar to controls in $\mathrm{CF}$ patients under $5 \mathrm{yr}$ old, but significantly higher in patients older than $5 \mathrm{yr}(\mathrm{p}<0.05)$. Pancreatic isoamylase activities were also similar to controls in younger CF patients, but were lower than controls in patients older than $5 \mathrm{yr}(\mathrm{p}<0.01)$. Only 18 of the 37 patients had PIA activities outside the control ranges (Fig. 1).



Fig. 1 Pancreatic isoamylase activities in CF patients. Dotted lines enclose the reference range from control subjects.
When PIA was expressed as a percentage of the total serum amylase ( $\%$ PIA), the age-related changes in control children were eliminated (Table), but the control range derived from the whole of the control group was now very wide (median \%PIA 34 , range $10-100 \%$ ). In $\mathrm{CF}, \%$ PIA was inversely correlated with age $(r=0.384, p=0.018)$, but expression of the PIA results in this way gave no advantage, as only $17 / 37$ patients had abnormal activities.

Serum IRT activities in control subjects did not vary with age, and a single reference range is shown in Fig. 2 (median control IRT activity $234.5 \mathrm{ng} / \mathrm{ml}$, range $112-463 \mathrm{ng} / \mathrm{ml})$. In $\mathrm{CF}$ patients IRT was inversely correlated with age $(\mathrm{r}=-0.585, \mathrm{p}=$ $0 \cdot 0003$ ). Activities were high in infants, fell through the normal range in the 1-9 yr age group, and were usually low in those older than $10 \mathrm{yr}$. Serum IRT activities were abnormal in $26 / 37 \mathrm{CF}$ patients overall, and in $14 / 15$ patients over $10 \mathrm{yr}$ of age.

Despite taking pancreatic supplements, $31 / 32$ $\mathrm{CF}$ patients tested had steatorrhoea (faecal fat values $13 \cdot 7-336 \mathrm{mmol} /$ day). Several young children

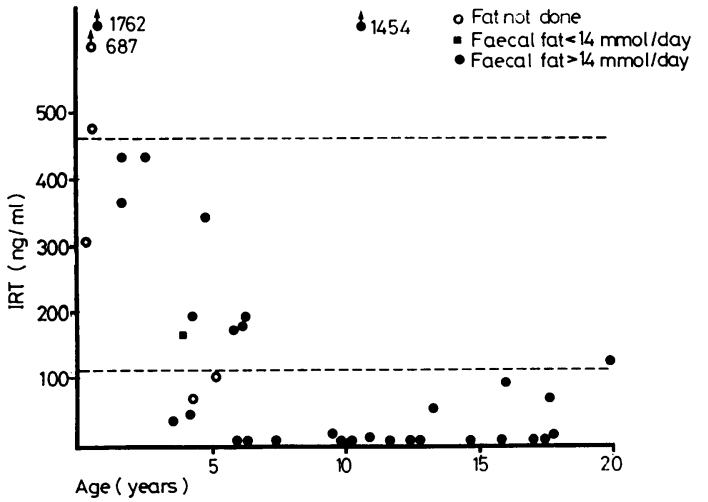

Fig. 2 Serum immunoreactive trypsin activities in $C F$ patients. Dotted lines enclose the reference range from control subjects. 
(aged 3-10 yr) with normal PIA or IRT activities already had steatorrhoea. In the older children ( $>10 \mathrm{yr}$ ) there was no relation between severity of steatorrhoea and normal or abnormal PIA or IRT values.

\section{Discussion}

This study compares PIA and IRT activities measured on the same sample of blood from CF patients of wide age-range, and from hospital controls including patients with conditions that could be confused with $\mathrm{CF}$.

Pancreatic isoamylase was less valuable than IRT as a diagnostic test, since fewer patients had abnormal PIA than IRT activities (18/37 $v 26 / 37$ respectively). This was mainly due to the very wide ranges for PIA found in the control children (Table). Previous workers using similar assay methods have also reported a wide range for PIA, and a marked overlap between CF patients and hospital controls. $^{11}$ Measurements of PIA using electrophoretic or other methods of separation of the isoamylases are reported to give a clearer distinction between CF patients and controls. ${ }^{4} 6$ However, in adult subjects, we have found the inhibitor method gives very similar results to an electrophoretic technique (Kelleher et al, unpublished results, 1982).

The diagnostic value of IRT was greatest in older patients, only one of our $15 \mathrm{CF}$ patients over $10 \mathrm{yr}$ old having IRT activities within the control range. This is important, as it is among older patients that the sweat test is most often difficult to interpret. ${ }^{12}$ In the 1-9 yr age group, less than half of our patients had abnormal activities, limiting the value of the test, though a low activity would still support the diagnosis of CF. Dandona et $a l^{8}$ also found low IRT values in older patients, but studied too few younger patients to assess the limitations of the test. Other workers using a different immunoassay have found a much greater overlap between IRT activities in CF patients and controls of all ages. ${ }^{13}$ Below the age of one year, the test may again be useful, since three of four patients had high IRT activities. Our findings support the suggestion that IRT measurement may be a useful screening test for $\mathrm{CF}$ in neonates. ${ }^{14} 15$

At least $31 / 32$ of our $C F$ patients had pancreatic insufficiency, judging by the persistence of steatorrhoea despite pancreatic enzyme supplements. We cannot therefore comment directly on PIA and IRT activities in patients without pancreatic insufficiency. However the finding of both normal or low PIA and IRT activities in patients with steatorrhoea makes it unlikely that either measurement will identify those few patients who do not need pancreatic supplements.

We conclude that PIA measurement using the inhibitor method is of little value as a diagnostic test for CF: In contrast IRT should be added to the range of tests helpful in those cases of CF where the sweat test is normal or equivocal. Immunoreactive trypsin is particularly useful in patients over 10 years old. Neither PIA nor IRT measurement is likely to be of value in assessing the need for pancreatic supplements in CF.

\section{References}

${ }^{1}$ Smalley CA, Addy DP, Anderson CM. Does that child really have cystic fibrosis. Lancet 1978;ii:415-7.

2 Davis PB, Hubbard VS, Di Sant Agnese PA. Low sweat electrolytes in a patient with cystic fibrosis. Am J Med 1980;69:643-6.

${ }^{3}$ Hadorn B. The exocrine pancreas. In: Anderson CM, Burke V, eds. Paediatric gastroenterology. Oxford: Blackwell Scientific Publications, 1975.

${ }^{4}$ Wolf RO, Taussig LM, Ross ME, Wood RE. Quantitative evaluation of serum pancreatic isoamylases in cystic fibrosis. J Lab Clin Med 1976;87:164-8.

${ }^{5}$ Skude G, Kollberg H. Serum isoamylases in cystic fibrosis. Acta Pediatr Scand 1976;65:145-9.

${ }^{6}$ Gillard BK, Simbala JA, Feig SA. Serum amylase isoenzymes in cystic fibrosis patients. Evidence for a generalised defect in exocrine gland secretory regulation. Pediatr Res 1980;14:1168-72.

${ }^{7}$ O'Donnell MD, FitzGerald O, McGeeney KF. Differential serum amylase determination by use of an inhibitor, and design of a routine procedure. Clin Chem 1977;23: 560-6.

${ }^{8}$ Dandona P, Hodson M, Bell J, Ramdial L, Beldon I, Batten JC. Serum immunoreactive trypsin in cystic fibrosis. Thorax 1981;36:60-2.

${ }^{9}$ Kamer JH van de, Huinink H, ten Bokkel, Weyers WA. Rapid method for the determination of fat in faeces. J Biol Chem 1949;177:347-55.

${ }^{10}$ Wilkinson R. Polyethylene glycol 4000 as a continuously administered non-absorbable faecal marker for metabolic balance studies in human subjects. Gut 1971;12:654-60.

${ }^{11}$ Kenny D, Cooke A, Tempany E, McGeeney KF. Activity of serum $\alpha$-amylases in cystic fibrosis. Clin Chim Acta 1978;89:429-33.

12 Anderson CM, Goodchild MC. Cystic fibrosis. Oxford: Blackwell, 1976:142.

${ }^{13}$ Burlina A, Rizzotti P, Tonon M, Mastella G. Serum immunoreactive trypsin in cystic fibrosis. Scand $J$ Gastroenterol 1980;15, suppl 62:35-43.

14 Elliott RB, Crossley JR. Neonatal dried blood spot screening for cystic fibrosis. In: Sturges JM, ed. Perspectives in cystic fibrosis. Toronto: Proceedings of the 8th International Cystic Fibrosis Congress, 1980:292-6.

${ }^{15}$ King DN, Heeley AF, Walsh MP, Kuzemko JA. Sensitive trypsin assay for dried-blood specimens as a procedure for early detection of cystic fibrosis. Lancet 1979;ii: 1217-9.

Requests for reprints to: Dr RC Brown, Department of Medicine, St James's Hospital, Leeds LS9 7TF, England. 